\title{
DIELECTRIC CONSTANT AND INDUCED DIPOLE MOMENT OF EDIBLE OILS SUBJECTED TO CONVENTIONAL HEATING
}

\author{
Margareta Pecovska-Gjorgjevich*, Aleksandar Andonovski, Julijana Velevska
}

\author{
Faculty of Natural Sciences and Mathematics, Institute of Physics, \\ Ss. Cyril and Methodius University, Skopje, Republic of Macedonia \\ *pecovska@pmf.ukim.mk; julev@pmf.ukim.mk
}

\begin{abstract}
The frequency dependence of the dielectric constant, the dielectric loss factor and conductivity were studied for five edible oils in the frequency range of $100 \mathrm{kHz}$ to $13 \mathrm{MHz}$ at different temperatures using frequency domain spectroscopy. The dielectric constant was similar for all the samples, in agreement with previous reports. The dielectric loss was low $(<0.01)$, except for virgin olive oil with a value of 0.05 . The dielectric loss peak frequency was $4 \mathrm{MHz}$ for corn oil and around 5.2 MHz for the others. At this frequency, conductivity was on the order of $10^{-7}-10^{-9} \mathrm{~S} / \mathrm{cm}$ and decreased with temperature, following the behavior of dielectric losses. The refractive index, molar and orientation polarization were calculated for all types of oils using the novel theory proposed by N. M. Putintsev and D. N. Putintsev. The data show that orientation polarization contributes to the observed dielectric constant at low temperatures and frequencies. This indicates that edible oils are not pure non-polar dielectrics. The induced dipole moments of the oils were calculated for $400 \mathrm{kHz}$ and $10 \mathrm{MHz}$ at $300 \mathrm{~K}$ and $318 \mathrm{~K}$. The results are discussed and correlated as a function of temperature and frequency to establish this relationship.
\end{abstract}

Key words: dielectric constant; edible oils; molar polarization; specific refraction, dipole moment

\section{ДИЕЛЕКТРИЧНА КОНСТАНТА И ИНДУЦИРАН ДИПОЛЕН МОМЕНТ НА МАСЛА ЗА ЈАДЕЊЕ ПОДЛОЖЕНИ НА КОНВЕНЦИОНАЛНО ГРЕЕЊЕ}

Испитувана е фреквенциска зависност на диелектричната константа, диелектричниот фактор на загуби и електричната спроводливост на пет масла за јадење во фреквентни интервал од 100 $\mathrm{kHz}$ до $13 \mathrm{MHz}$ при неколку температури. Диелектричната константа има блиски вредност за сите примероци и се сложува со податоците од литературата. Диелектричните загуби се мали $(<0,01)$ освен за маслиновото масло кое има вредност од 0,05 . Фреквенцијата на максимумот на диелектрични загуби е $4 \mathrm{MHz}$ за пченкарното масло и околу $5,2 \mathrm{MHz}$ за сите други. Спроводливоста мерена на оваа фреквенција е од ред на $10^{-7}-10^{-9} \mathrm{~S} / \mathrm{cm}$, највисока за маслиновото масло и се намалува со температурата, следејќ́ го однесувањето на диелектричните загуби. Од пресметаните вредности на моларната поларизација на оптички фреквенции, моларната поларизација и ориентационата поларизација, при што е користена теоријата на Н. М. Путинчев и Д. Н. Путинчев, се забележува влијанието на ориентационата поларизација врз однесувањето на диелектричната константа при пониски температури и ниски фреквенции. Ова доведува до заклучок дека маслата не се чисто неполарни диелектрици, туку пројавуваат мала поларност. Пресметани се диполните моменти за 400 $\mathrm{kHz}$ и $10 \mathrm{MHz}$ при температури од $300 \mathrm{~K}$ и $318 \mathrm{~K}$. Набљудувана е промената на диполниот момент во зависност од температурата и фреквенцијата.

Клучни зборови: диелектрична константа; масла за јадење; моларна поларизација; моларна рефракција; диполен момент 


\section{INTRODUCTION}

Currently, mineral oil is widely used as a basic insulator material in industry as it has a low cost and excellent dielectric and cooling properties [2-4]. It is poorly biodegradable and contaminating to soil and its stocks decrease every year because it is non-renewable. A shortage is expected very soon, in the middle of the 21 st century, so there are demands for alternative materials with improved efficiency to replace mineral oil [2-4]. Vegetable oils are being seriously considered as candidates for this purpose. Technically, natural oils with unsaturated fatty acids have attracted great attention for their use in medical, food and industrial materials. They have already replaced mineral oil in some outdoor small transformers in US [5]. Natural esters have very acceptable properties, such as their renewability and their ability to biodegrade (70 $\%-100 \%$ ) with very little or no toxicity [6], which makes them environmentally friendly. They are chemically and temperature stable with a high degree of water solubility (20 to 30 times more than mineral oil), which decreases the effect of humidity on insulator strength [2]. This leads to low relative water content in vegetable oils and a higher breakdown voltage than mineral oil. The breakdown voltage is highly influenced by impurities like water, gases and particles present in oils.

Edible oils are natural esters formed from glycerol and triglycerides. Some of them have two or three different fatty acids. Fatty acids are saturated if the carbon atoms in the molecule are connected with single bonds. Sometimes, fatty acids are converted from saturated to monounsaturated, with the loss of one hydrogen atom, and the single bond between carbon atoms becomes double. If there is more than one double bond, the fatty acid becomes polyunsaturated. Every vegetable oil has its own composition with different ratios of unsaturated with saturated fatty acids. Oils with a higher content of unsaturated acids are liquid at room temperature. The nature of the oil depends on its constituent fatty acids. Their variation can change the oil's physical and chemical properties, which enables them to be a good replacement for mineral oil.

To characterize any vegetable oil, it is necessary to know its properties like density, molecular weight, acid value, saponification value, iodine value, refractive index and dielectric behavior. The molecular weight of edible oils is very difficult to calculate due to the unavailability of these oils in pure compounds. Edible oils usually exist as a mixture of different fatty acids. In this study, we used the saponification value in order to estimate the molecular weight of the oils under consideration. It should be noted that the saponification value (SV) is the number of milligrams of potassium hydroxide required to saponify $2 \mathrm{~g}$ of oil. A lower saponification value indicates a larger molecular weight of the fatty acid [8]. The density of different types of vegetable oils is similar, within the interval $910-930 \mathrm{~kg} / \mathrm{m}^{3}$ [9].

In order to provide monitoring for quality control during production processes, several methods were applied. Highly sophisticated methods for analysis of oils have already been developed, such as liquid chromatography [10], Fourier transform infrared (FTIR) spectroscopy [11], Raman spectroscopy [12] and nuclear magnetic resonance (NMR) [13]. All these methods are very expensive and unsuitable for quality control in oil processing industries. A method like frequency domain dielectric spectroscopy is easy to apply for industrial monitoring applications. Frequency domain dielectric spectroscopy is also a low-cost method. In this study, we used this method to monitor the quality characteristics of natural oils. In industrial liquid processing, properties like density, refractive index and the amount of polar components should be correlated with the dielectric parameters obtained using this method [6, 14]. The study of the dielectric properties of oils is a good source of information about their behavior. The dielectric constant, dielectric losses, conductivity and dipole 
moment are related to the functioning of the oil for a specific application. This article presents detailed studies of these dielectric properties for five types of vegetable oil. On the basis of their dielectric behavior, the investigated oils were ranked in order to find the most suitable oil for insulator industrial applications.

\section{EXPERIMENTAL}

The vegetable oils were purchased from local markets. Their composition was provided by the manufacturers. The ratio of unsaturated/ saturated fats, saponification value and molecular weight are given in Table 1.

Values for palm oil contents were taken from the literature for the most common palm oil [7], as they were not available from the manufacturer. Saponification values (SV) were taken from the literature $[8,9,15,16]$ and average values are used. The molecular weight $M_{w}$ was calculated by the relation $M_{w} \cdot \mathrm{SV}=168300$ ( $M_{w}$ is given in $\mathrm{g} / \mathrm{mol}$ ) [9].

The densities of the oils were measured at room temperature by a gravimetric method with the accuracy of the balance at $10^{-4} \mathrm{~g}$. The dielectric constant at optical high frequency $\varepsilon_{\infty}=n^{2}$ was determined by measuring the refractive indices of the oils at $298.15 \mathrm{~K}$ with a Carl Zeiss Abbe refractometer (Bellingham \& Stanley 60-70) with a precision of $1 \times 10^{-4}$ at a wavelength of $589 \mathrm{~nm}$.
The dielectric measurements were performed using an LF Impedance Analyzer HP 4192 A with an applied voltage of $1 \mathrm{~V}$. The samples were put in HP 16452A Liquid Test Fixture with an electrode diameter of $38 \mathrm{~mm}$ and a fluid gap of $0.3 \mathrm{~mm}$ in parallel mode. For all samples, the capacitance $C_{0}$ of the empty cell, the capacitance $C_{p}$ of the cell filled with oil, the conductance $G$ and dielectric loss $\tan \delta$ were measured in the frequency range $100 \mathrm{kHz}$ to $13 \mathrm{MHz}$ at different temperatures from 300.15 to $318.15 \mathrm{~K}$. The temperature of the investigated samples was measured in situ with an accuracy of 0.01 K. Dielectric constant $\varepsilon^{\prime}$, dielectric loss factor $\varepsilon^{\prime \prime}$ and $a c$ electrical conductivity $\sigma$ were calculated using the following equations $[2,17]$ :

$$
\begin{gathered}
\varepsilon^{\prime}=\frac{C_{p}}{C_{0}} \\
\varepsilon^{\prime \prime}=\varepsilon^{\prime} \cdot \tan \delta \\
\sigma=G \cdot \frac{d}{S}=\varepsilon_{0} 2 \pi f \varepsilon^{\prime \prime}
\end{gathered}
$$

where $S$ is the area of the injecting electrode, $d$ is the fluid gap and $\varepsilon_{0}$ is permittivity of free space. The conductance $G$ is related to dielectric loss as $G=2 \pi f C_{\mathrm{p}} \tan \delta, f$ is the linear frequency of the applied electric field.

Table 1

Characteristics of the oils used in this study

\begin{tabular}{lcccccc}
\hline \hline Type of oil & $\begin{array}{c}\text { Saturated fats } \\
\%\end{array}$ & $\begin{array}{c}\text { Monounsa- } \\
\text { turated, \% }\end{array}$ & $\begin{array}{c}\text { Polyunsa- } \\
\text { turated, } \%\end{array}$ & $\begin{array}{c}\text { Ratio } \\
\text { uns : sat }\end{array}$ & SV & $\begin{array}{c}M_{w} \\
\left(10^{-3} \mathrm{~kg} / \mathrm{mol}\right)\end{array}$ \\
\hline Palm & 50 & 40 & 10 & 1 & $187-206$ & $863.39 \pm 22.29$ \\
Olive (ac. $<1.5 \%)$ & 15.9 & 73 & 9.5 & 5.2 & $185-200$ & $886.67 \pm 48.00$ \\
Corn & 12 & 26 & 61 & 7.25 & $187-193$ & $853.60 \pm 46.40$ \\
$\begin{array}{l}\text { Sunflower } \\
\text { (cold pressed) }\end{array}$ & 11 & 34 & 55 & 8.1 & $188-194$ & $886.18 \pm 18.66$ \\
$\begin{array}{l}\text { Rapeseed } \\
\text { (cold pressed) }\end{array}$ & 6.7 & 58.9 & 30 & 13.3 & $194-197$ & $860.92 \pm 6.64$ \\
\hline \hline
\end{tabular}


The dielectric character of the investigated oils was established by studying the variation in the dielectric constant, dielectric losses and conductivity of the samples with changes in temperature.

\section{THEORETICAL BACKGROUND}

A molecule has an electric dipole moment if it has a net separation of the centers of the positive and negative charges (dipoles). If dipoles exist in the molecule without the application of an electric field, it has a constant electric dipole moment. If we apply an electric field to a molecule which has no dipoles, an induced dipole moment will appear through interaction with the field.

The dielectric constant represents the sum of two different component properties of materials: the deformation polarizability $\alpha_{\text {def }}$ and the constant dipole moment of the molecules $\mu$. Polarizability $\alpha_{\text {def }}$ measures the interaction of the electrons in a molecule with the electric field and is defined as the magnitude of the proportionality between the induced dipole moment $\mathbf{p}$ and the local electric field $\mathbf{F}$ :

$$
\mathbf{p}=\alpha_{\mathrm{def}} \cdot \mathbf{F}
$$

Until recently, the Lorenz-Lorenz equation was considered a good approximation for non-polar or weakly polar substances and the molar refraction value was assumed to be the molecular constant of the substance under consideration [18]. In the last few years, this equation has been modernized by considering that thermal motion continuously reorients the molecule dipoles in liquids, thus causing an interaction between them; therefore, the values of electron polarizability $\alpha_{\mathrm{el}}$ of the molecules changes with changes in the energy state [1921]. This theory is based on the assumption that the energy of substance polarization in low electric fields virtually equals the interaction energy; an explanation is given elsewhere [1]. According to this novel theory proposed by $\mathrm{N}$.
M. Putintsev and D. N. Putintsev, the equation for calculating molar polarization $P_{M}$ is:

$$
P_{M}=\left(\varepsilon_{s}-1\right) \cdot V_{0}=\frac{N_{A}}{\varepsilon_{0}} \cdot\left(\alpha_{\mathrm{def}}+\frac{\mu^{2}}{3 k T}\right)
$$

where $\varepsilon_{\mathrm{s}}$ is the static dielectric constant, $V_{0}=$ $M_{w} / \rho$ is the molar volume, $\rho$ is the density and $M_{w}^{w}$ is the molecular weight of the oil, $k$ is the Boltzman constant, $T$ is the absolute temperature and $N_{A}$ is Avogadro's number. Molar polarization contains two contributions, one due to constant electric dipoles, $P_{M c}$, and the second, $P_{M \text { def }}$, known as molar deformation polarization, due to induced electric dipoles caused by distortion of the electronic cloud. Natural oils are mainly non-polar dielectrics and the second term (constant dipole moment) is neglected. In this case, equation (5) transforms to equation (6) and we can calculate the deformation molar polarization as:

$$
P_{M}=P_{M \text { def }}=\left(\varepsilon_{\text {def }}-1\right) \cdot V_{0}=\frac{N_{A}}{\varepsilon_{0}} \cdot \alpha_{\text {def }}
$$

To determine the contribution of constant dipoles, if any, one must estimate the contribution of induced dipoles. This can be done by knowing that at high frequencies of visible light, constant dipoles make essentially no contribution to polarization. A measure of the dielectric constant at these conditions allows us to estimate the contribution of induced dipoles. The dielectric constant at these optical frequencies is related to the refractive index by a simple formula $\left(\varepsilon_{\infty}=n^{2}\right)$. From here, we can obtain the molar refraction (molar polarization at optical frequencies), $R_{M}$, of the oils, defined by the following equation [1]:

$$
R_{M}=\left(n^{2}-1\right) \cdot V_{0}=\frac{N_{A}}{\varepsilon_{0}} \alpha_{\mathrm{el}}
$$

where $\alpha_{\mathrm{el}}$ is the electron polarizability.

In non-polar liquids, the difference between $P_{M}$ and $R_{M}$ should be zero, since it reflects the contribution of orientation polarization. By investigating the temperature 
dependence of the dielectric constant we can establish what kind of polarization the investigated oils have and separate electronic from dipole (orientation) polarization. We assume that the orientation molar polarization $P_{M}$ or is a measure of the difference between the molar polarization $P_{M}$ (polarization at low frequencies) and the molar refraction $R_{M}$ (polarization at optical frequencies), i.e.:

$$
P_{M, \text { or }}=P_{M}-R_{M}
$$

The induced dipole moment $p$ can be calculated from the following equations, where the relationship between the energy of interaction and the polarization characteristics of a compound has been established $[1,22]$ :

$$
\begin{gathered}
N_{A} \alpha_{\text {def }} F^{2}=2 U_{\mathrm{int}} \\
L\left(x_{F}\right)=\frac{2 U_{\mathrm{int}}}{2 U_{\mathrm{int}}+R T} \\
p^{2}=\frac{k T}{L\left(x_{F}\right)} \frac{\varepsilon_{0}}{N_{A}} P_{M}
\end{gathered}
$$

where $L\left(x_{F}\right)$ is the Langevin function, $F$ is the electric field responsible for deformation polarization of the system, $U_{\text {int }}$ is the internal energy of the interaction and $R=8.314 \mathrm{~J} / \mathrm{mol} \mathrm{K}$. $k T$ in equation (11) represents the amount of thermal energy available. In liquids, thermal motion continuously changes the orientation of dipoles. Using this relation, we see large molecules of vegetable oils as rotating rigid structures. In an oscillating electric filed, the entire molecule has to rotate. From the dipole moment of these molecules, we can estimate the dimensions of the molecules by the relation $\mathbf{l}=\mathbf{p} / Q$ if we know the electric charge of the molecule $Q$. Here, I represents the distance between the positive and negative charge in the molecule.

\section{RESULTS AND DISCUSSION}

Figure 1 shows the temperature dependence of the real part of the complex dielectric constant $\varepsilon^{\prime}\left(\varepsilon^{*}=\varepsilon^{\prime}+\varepsilon^{\prime \prime}\right)$ for edible oils measured at $400 \mathrm{kHz}$. This frequency is assumed to be very low and the values of dielectric constants are considered static when $d c$ current is applied through the sample. There is no dependence of $\varepsilon^{\prime}$ on the amount of monounsaturated, polyunsaturated or saturated acids in the composition of the oils, although in [9], increased $\varepsilon^{\prime}$ of oils was connected to an increase in the unsaturation of the oil. A decrease in the dielectric constant with increasing temperature (Figure 1) was observed over the range of temperature studied. The density of the oils decreased slightly with increasing temperature, which is directly related to the density of the dipoles. An increase in temperature causes an increase in kinetic energy, i.e. the velocity of the molecules, thus causing an increase in the chaotic movement and a decrease in the dipole orientation, which decreases $\varepsilon^{\prime}$. The value of $\varepsilon^{\prime}$ for all vegetable oils was in the interval of 3.1-3.2 at room temperature. In comparison to $\varepsilon^{\prime}$ of mineral oil (2.2) it is higher, suggesting that these oils can be used in transformers as a dielectric coolant $[2,3]$.

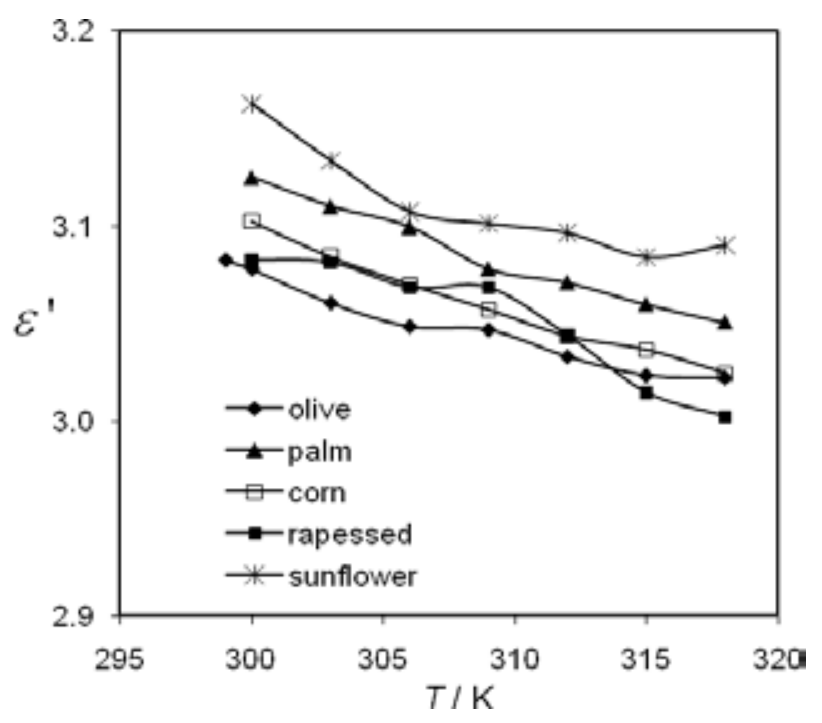

Fig. 1. Temperature dependence of $\varepsilon^{\prime}$ for five vegetable oils at $400 \mathrm{kHz}$ 
Figure 2 shows the behavior of the imaginary part of permittivity $\varepsilon^{\prime \prime}$ as a function of temperature. The values of $\varepsilon^{\prime \prime}$ for each oil are given at the peak frequency where the dielectric loss was highest. This value corresponds to the relaxation time frequency and was similar for all oils, $5.2 \mathrm{MHz}$, except for corn oil at $4 \mathrm{MHz}$. Here, we see an enhanced value of $\varepsilon^{\prime \prime}(\sim 0.05)$ for olive oil compared to the other oils $(<0.01)$, indicating a higher amount of impurities such as relative water content and/or the non-symmetrical structure of the olive oil molecule. These results agree with the literature [3], where an increase in dielectric losses in green olive oil was attributed to the presence of carotene and chlorophyll. Also, an increase in temperature reduced the relative water content in the oil, i.e. this decreased the degree of polarization of the oil. Dielectric losses are influenced by polarization and also decrease with temperature. Our results are in good agreement with the data given in the literature with values of $\varepsilon^{\prime \prime}$ of 0.22 [3], 0.45 [8], 0.01 [2], 0.1 [4] and 0.35 [6].

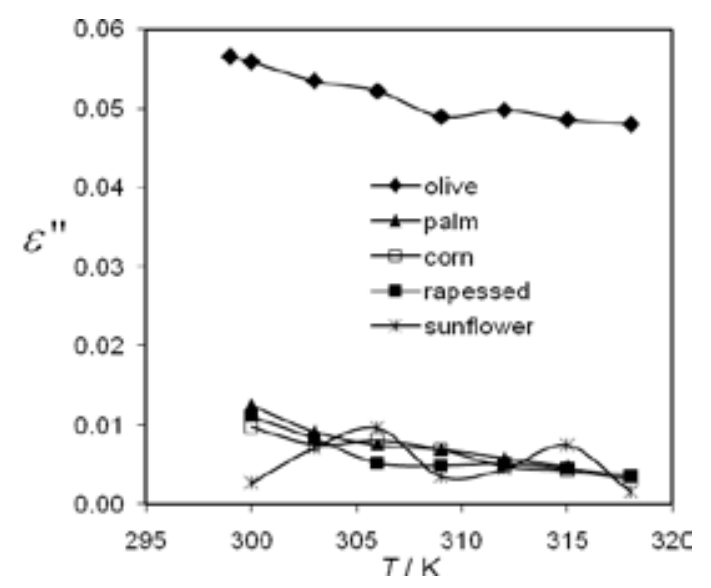

Fig. 2. Dielectric loss $\varepsilon^{\prime \prime}$ as a function of temperature at peak frequency for the investigated oils

Figure 3 presents the behavior of ac electrical conductivity with variable temperature for the investigated oils at the same frequency as the peak frequency of $\varepsilon^{\prime \prime}$. It can be seen that the values of conductivity were very low, from $10^{-7}$ to $10^{-9} \mathrm{~S} / \mathrm{cm}$; the highest was observed for olive and the lowest for corn oil. A very slow decrease in conductivity with increasing temperature was observed, which confirms the re- sults for the dielectric loss factor $\varepsilon^{\prime \prime}$. Olive oil showed the most stable state with no fluctuation in the temperature dependence due to the deterioration of heated oil, which was the most pronounced for sunflower oil. The biggest decrease in conductivity was observed for rapeseed oil.

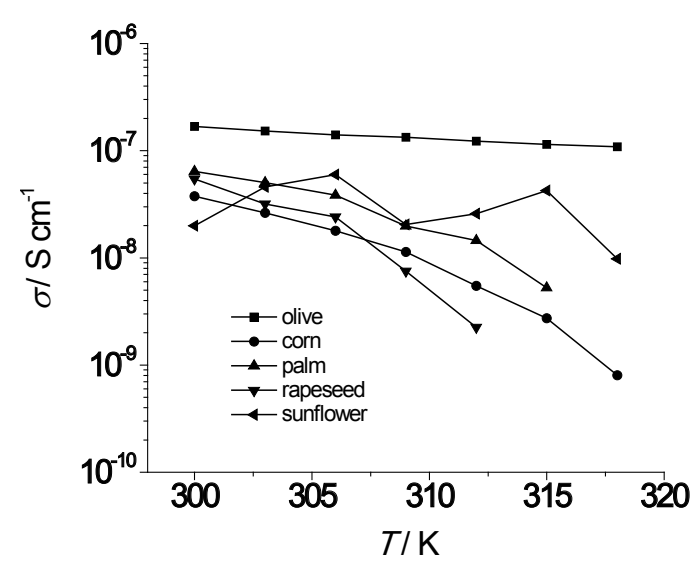

Fig. 3. The variation in conductivity with temperature at $5.2 \mathrm{MHz}$

Figure 4 shows the decrease in the dielectric constant for corn oil as a function of temperature measured for different frequencies of the applied electric field. This behavior is normal for almost all materials, because at higher frequencies there is insufficient time for the molecule to rotate, i.e. the orientation polarization decreases with a tendency to disappear; therefore, at these frequencies, only the polarizability term contributes to the dielectric constant [23]. However, significant changes were observed at higher frequencies and temperatures. The behavior of the other oils was similar to the behavior of corn oil.

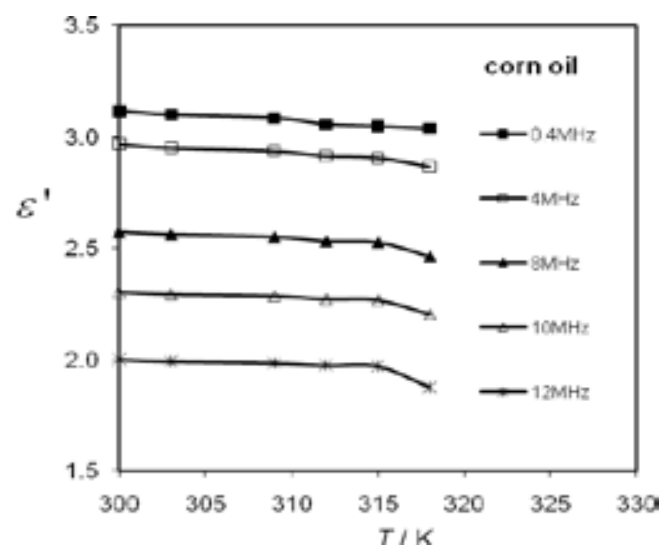

Fig. 4.Temperature dependence of the dielectric constant for corn oil at five different frequencies 
Table 2 presents the measured values of density, the refractive index and the calculated values of high frequency dielectric permittivity at $298.15 \mathrm{~K}$. The values of the real part of dielectric permittivity for the lowest $(300.15 \mathrm{~K})$ and highest $(318.15 \mathrm{~K})$ temperatures implemented in the measurements of the investigated oils are also shown. We used this temperature interval to avoid high temperature oxidation processes which can create primary and secondary products and change the com- position of oils and their characteristics. Temperatures up to $318 \mathrm{~K}$ can still be considered room temperature.

From equation (7), we estimated the molar refraction $R_{M}$ for each oil; the data are presented in Table 2. It was found that molar refraction was very similar for all types of natural oils with an average value of $R_{M}=(1.102$ $\pm 0.008) \times 10^{-3} \mathrm{~m}^{3} / \mathrm{mol}$. This means that the values of molar refraction cannot be used as a characteristic to differentiate the oils.

Table 2

Density $\rho$, refractive index $n$ and dielectric constant at $300.15 \mathrm{~K}$ and $318.15 \mathrm{~K}$, optical dielectric constant $\varepsilon_{\infty}$ and molar refraction $R_{M}$ for five types of vegetable oI

\begin{tabular}{lcccccccc}
\hline \hline \multirow{2}{*}{ Type of oil } & \multirow{2}{*}{$\rho\left(\mathrm{kg} / \mathrm{m}^{3}\right)$} & \multirow{2}{*}{$n$} & $\varepsilon^{\prime}, 300.15 \mathrm{~K}$ & $\varepsilon^{\prime}, 318.15 \mathrm{~K}$ & $\varepsilon^{\prime}, 300.15 \mathrm{~K}$ & $\varepsilon^{\prime}, 318.15 \mathrm{~K}$ & $\varepsilon_{\infty}$ & \multicolumn{2}{c}{$R_{M}$} \\
& & & $400 \mathrm{kHz}$ & $400 \mathrm{kHz}$ & $10 \mathrm{MHz}$ & $10 \mathrm{MHz}$ & $298.15 \mathrm{~K}$ & $10^{-3} \mathrm{~m}^{3} / \mathrm{mol}$ \\
\hline Palm & 919.91 & 1.4670 & 3.138 & 3.028 & 2.333 & 2.297 & 2.152 & 1.081 \\
Olive & 916.19 & 1.4690 & 3.096 & 3.014 & 2.303 & 2.283 & 2.158 & 1.121 \\
Corn & 921.38 & 1.4730 & 3.115 & 3.036 & 2.303 & 2,201 & 2.169 & 1.084 \\
Sunflower & 923.98 & 1.4735 & 3.166 & 3.063 & 2.365 & 2.321 & 2.171 & 1.123 \\
Rapeseed & 913.65 & 1.4725 & 3.109 & 3.106 & 2.317 & 2.264 & 2.168 & 1.101 \\
\hline \hline
\end{tabular}

Using the values of the dielectric constant at two different temperatures $(300.15 \mathrm{~K}$ and $318.15 \mathrm{~K}$ ) and two different frequencies (400 kHz and $10 \mathrm{MHz}$ ) we calculated the molar polarization, $P_{M}$ using equation (6). Obtained values are presented in Table 3 .

As can be seen, $P_{M}$ and $R_{M}$ differ in their values. The temperature dependence of the di- electric constants shows that the value of $\varepsilon^{\prime}$ decreases with increasing temperature, indicating the presence of a certain dipole moment, i.e. the oils are not purely non-polar (for such dielectrics, $\varepsilon^{\prime}$ does not depend on temperature). This means that a decrease in orientation polarization occurs, resulting in absorption in the millimeter range [24].

Table 3

Molar polarization $P_{M}$, molar orientation polarization $P_{M, o r}$ and induced dipole moment $p$ for all the oils investigated at $400 \mathrm{kHz}$ and $10 \mathrm{MHz}$ at two temperatures of heating, $300.15 \mathrm{~K}$ and $318.15 \mathrm{~K}$

\begin{tabular}{lcccc|ccr}
\hline \hline Type of oil & Frequency & $\begin{array}{c}P_{M} \cdot 10^{3} \\
\left(\mathrm{~m}^{3} / \mathrm{mol}\right)\end{array}$ & $\begin{array}{c}P_{M, \mathrm{or}} \cdot 10^{3} \\
\left(\mathrm{~m}^{3} / \mathrm{mol}\right)\end{array}$ & $p(\mathrm{D})$ & $\begin{array}{c}P_{M} \cdot 10^{3} \\
\left(\mathrm{~m}^{3} / \mathrm{mol}\right)\end{array}$ & $\begin{array}{c}P_{M, \text { or }} \cdot 10^{3} \\
\left(\mathrm{~m}^{3} / \mathrm{mol}\right)\end{array}$ & $\begin{array}{c}p(\mathrm{D}) \\
\text { Palm }\end{array}$ \\
\hline \multirow{2}{*}{ Olive } & $400 \mathrm{kHz}$ & 2.007 & 0.926 & 1.926 & 1.936 & 0.855 & 1.850 \\
& $10 \mathrm{MHz}$ & 1.251 & 0.170 & 0.824 & 1.217 & 0.136 & 0.738 \\
\hline \multirow{2}{*}{ Corn } & $400 \mathrm{kHz}$ & 2.028 & 0.908 & 1.957 & 1.963 & 0.842 & 1.887 \\
& $10 \mathrm{MHz}$ & 1.261 & 0.140 & 0.770 & 1.242 & 0.121 & 0.715 \\
\hline \multirow{2}{*}{ Sunflower } & $400 \mathrm{kHz}$ & 1.959 & 0.875 & 1.852 & 1.887 & 0.803 & 1.774 \\
& $10 \mathrm{MHz}$ & 1.207 & 0.123 & 0.695 & 1.113 & 0.029 & 0.337 \\
\hline \multirow{2}{*}{ Rapeseed } & $400 \mathrm{kHz}$ & 2.078 & 0.954 & 2.007 & 2.020 & 0.897 & 1.946 \\
& $10 \mathrm{MHz}$ & 1.309 & 0.186 & 0.886 & 1.267 & 0.144 & 0.780 \\
\hline
\end{tabular}


Using equation (8), we calculated the orientation polarization $P_{M, o r}$. The values are given in Table 3. The value of $P_{M, o r}$ decreased rapidly with increasing frequency of the applied field and should be zero at optical frequencies. We also observed a decrease in $P_{M, o r}$ with increasing temperature, but this was not as fast. Finally, we calculated the values of induced dipole moment $p$, expressed in Debyes, $1 \mathrm{D}=$ $3.3564 \times 10^{-30} \mathrm{Cm}$. The data are given in Table 3 .

In liquids, thermal motion continuously changes the orientation of dipoles, unlike solids where the crystal structure freezes the dipoles in a fixed geometrical orientation, or in gases where the distance between the molecules is large and the interaction between dipoles is weak. Because of thermal motion, the orientation and movement of molecular dipoles present in the system cause dielectric changes in liquids. The dipole moment contribution to the dielectric constant shows a direct inverse temperature relationship [25]. Mineral oil contains much less polar material and therefore has a small dipole moment contribution. Therefore, less change in $\varepsilon^{\prime}$ is observed with heating [26]. The dielectric constant of natural oil $(\sim 3.1)$ is higher than that of mineral oil (2.2), because the dislocated electrons in the molecule are more polarizable. This is the reason for the higher orientation polarization in natural oils.

The obtained values for the dipole moment were in interval of 2.007 to $1.852 \mathrm{D}$. Compared to the literature [9] where $p$ is around $2.5 \mathrm{D}$, our calculations gave lower values for the dipole moment. The reason for this might be our novel approach using the novel Putintsev theory, instead of the well-established Debye theory used in previous studies [9]. The composition of the oils is also probably the reason for lower values of $p$ since all the investigated oils are virgin, cold pressed and with no additives which can increase $p$. The highest value of $p$ for sunflower oil leads us to conclude that molecules in this oil can rotate with high velocity, i.e. they are the smallest molecules, and the lowest value of $p$ for corn oil indicates the slowest molecules with the greatest length. This also means that the relaxation time of the dielectric relaxation process in sunflower oil is shorter than in corn oil, i.e. the dielectric relaxation process is fastest in sunflower oil and is slowest in corn oil.

As we can see, the dipole moment decreases with increasing frequency and temperature. The frequency dependent changes of $p$ are not so much pronounced and are attributed to the disability of dipole molecules to rotate with the frequency of the electric field. At room temperature, these changes are small and similar for all oils. The greatest changes at $318.15 \mathrm{~K}$ were observed for corn oil and lowest for olive oil, indicating that the presence of polyunsaturated fats influences these changes. Corn oil has a high content of polyunsaturated fats (61\%) while olive oil has a low content $(10 \%)$.

Heating of the oils enhanced the decrease in the dipole moment, confirming the inverse temperature dependence. During heating, oxidation processes take place in fatty acids, creating primary (hydroperoxide derivates, ketones, etc.) and secondary products. In our previous work [27], we defined the oxidation processes during the heating of oils using UV spectroscopy. Olive oil showed no significant oxidation of polyunsaturated fats and only oxidation of monounsaturated fats was observed, while sunflower oil (with a similar content of mono and polyunsaturated fats as corn oil) showed changes in the UV spectrum, indicating the presence of primary products of monounsaturated fats and polyunsaturated fat oxidation. An increased amount of these products during oxidation can explain the rapid decrease in the dipole moment which was especially pronounced in corn oil and sunflower oil. The decreased dipole moment led to increasing relaxation time, i.e. the relaxation process that took place in the oils was slowed down.

From what we observed here, although all the oils are considered suitable, virgin olive oil appeared to be the best candidate for industrial applications, as it showed the most stable behavior during heating and the smallest changes in the dipole moment. 


\section{CONCLUSION}

We have measured the optical and dielectric properties of five edible oils. The dielectric constant, dielectric losses and conductivity were measured at different temperatures. The results show the temperature dependence of the dielectric constant, indicating the presence of electric moment in the oils. The conductivity of the samples measured at frequencies that correspond to the peaks of dielectric losses was low and almost independent of temperature in this interval, confirming the low values of the dipole moment. The calculated molar refraction and molar polarization showed that $R_{M}$ was similar for all types of investigated oils with an average value of $(1.102 \pm 0.008) \times 10^{-3} \mathrm{~m}^{3} / \mathrm{mol}$, and is not a good indicator to make a distinction of the dielectric characteristics of the oils. The molar polarization decreased strongly with increasing frequency and temperature. The orientation molar polarization of the samples showed a decrease, especially at higher frequencies, which is normal behavior when approaching zero at optical frequencies. We have also observed a decrease of the dipole moment with increasing temperature and frequency. Most pronounced effect of the decreasing dipole moment was observed for the oil with the highest level of polyunsaturated fats $(61 \%)$, corn oil, while most stable behavior was observed for olive oil with the lowest level of polyunsaturated fats $(10 \%)$.

This behavior confirms the results from our previous work [27], where we connected changes in the UV spectra of oils with oxidation processes that took place during heating of the samples. An increasing amount of primary products during oxidation is a likely explanation for the rapid decrease in the dipole moment, which was especially pronounced in corn oil, where the oxidation of polyunsaturated fats is significant. This increases the relaxation time, which slows down the relaxation process in oils.

Although virgin olive oil showed the best characteristics for industrial applications, the most stable behavior during heating and the smallest changes in the dipole moment, further investigations are needed, especially in the higher temperature region, where significant changes in dielectric behavior are expected. Also, defining the breakdown voltage is necessary, as it is a very important quantity for the industrial application of vegetable oils. The influence of the fat content could be significant in improving the dielectric properties of oils, so UV spectroscopy analysis with heating of all types of oils is needed.

\section{REFERENCES}

[1] N. M. Putintsev, D. N. Putintsev, The Theory of Polarization of Molecular Systems, FIZMATLIT, Moscow, 2011.

[2] Z. H. Shah, Q. A. Tahir, Dielectric properties of vegetable oils, J. Sci. Res., 3, 481-492 (2011).

[3] I. L. Hosier, A. Guushaa, A. S. Vaughan, S. G. Swingler, Selection of a suitable vegetable oil for high voltage insulation application, J. Phys: Conference Series, 183, 1-5 (2009).

[4] Suwarno, I. S. Darma, Dielectric properties of mixtures between mineral oil and natural ester from palm oil, WSEAS Trans. Pow. Sys., 2, 37-46 (2008).

[5] L. A. T. Honory, Biodegradable/bio-based lubricants and greases, Mach Lubr M 200109 Noria Corp. (2004).

[6] P. Semancik, R. Cimbala, I. Kolcunova, Dielectric analysis of natural oils, Acta Electrotech. Inf., 3 , $1-5$ (2007).

[7] S. Aditama, Dielectric properties of palm oils as liquid insulating materials: effects of fat content, Proceedings of 2005 International Symposium on Electrical Insulating Materials (ISEIM 2005), 1, 91-94, 2005.

[8] S. Agrawal, D. Bhatnagar, Dielectric study of binary mixtures of edible unsaturated oils, Ind. $J$. Pure \& Appl. Phys., 43, 624-629 (2005).

[9] D. Rudan-Tasic, C. Klofutar, Characteristics of vegetable oils of some Slovene manufacturers, Acta Chim. Slov., 46, 511-521 (1999).

[10] A. H. El-Hamdy, N. K. El-Fizga, Detection of olive oil adulteration by measuring its authenticity factor using reversed-phase high-performance liquid chromatography, J. Chrom., 708, 351-355 (1995). 
[11] A. Tay, R. K. Singh, S. S. Krishnan, J. P. Gore, Authentication of olive oil adulterated with vegetable oils using Fourier transform infrared spectroscopy, Leb. Wiss. Tech., 35, 99-103 (2002).

[12] F. Guimet, J. Ferre, R. Boque, Rapid detection of olive-pomace oil adulteration in extra virgin olive oils from the protected denomination of origin Siurana using excitation-emission fluorescence spectroscopy and three-way methods of analysis, Anal. Chim. Acta, 544, 143-152 (2005).

[13] R. Sachhi, F. Adeo, L. Polillo, H and 13C NMR of virgin olive oil. An overview, Magn. Res. Chem., 35, 133-145 (1997).

[14] A. Cataldo, E. Piuzzi, G. Cannazza, E. De Benedetto, L. Tarricone, On the use of dielectric spectroscopy for quality control of vegetable oils, Proceedings of XIX IMEKO World Congress Fundamental and Applied Metrology, Lisbon, Portugal, 433-437 (2009).

[15] E. Stauffer, A Review of the analysis of vegetable oil, residues from fire Debris samples: spontaneous ignition, vegetable oils, and the forensic approach, J. Forensic Sci., 50, 1-10 (2005).

[16] F. D. Gunstone, The chemistry of oils and fats, Blackwell Pub. Technology \& Engineering, 2004.

[17] A. Javed, M. Akram, M. I. Shafiq, Dielectric properties of cholesterol derivates, Rom. J. Phys., 51, 819-826 (2006).

[18] N. M. Putintsev, D. N. Putintsev, The molar polarization and refraction of substances, Rus. J. Phys. Chem. A, 80, 1949-1952 (2006).
[19] N. M. Putintsev, D. N. Putintsev, A method for predicting the polarization of substances, Russ. J. Phys. Chem. A, 82, 1309-1315 (2008).

[20] N. M. Putintsev, D. N. Putintsev, Deformation polarization of substances, Russ. J. Phys. Chem. A, 81, 565-571 (2007).

[21] N.M. Putintsev, D.N. Putintsev, The permittivity of polar dielectrics, Russ. J. Phys. Chem. A, 81, 572-575 (2007).

[22] N. M. Putintsev, D. N. Putintsev, High-frequency dielectric permittivity of water and its components, Russ. J. Phys. Chem. A, 85, 1113-1118 (2011).

[23] B. P. Caldwell, H. F. Payne, Dielectric constant and effective dipole moment of drying oils, Ind. Eng. Chem., 33, 954-960 (1941).

[24] V. V. Shevlyakov, Orientation polarization and dielectric dispersion characteristics of nonpolar liquid solutions, Fizika, 11, 13-17 (1986).

[25] F. Ferreira de Sousa, S. G. C. Moreira, S. J dos Santos da Silva, J. Del Nero, P. Alcantara Jr., Dielectric properties of oleic acid in liquid phase, $J$. Bionanosci., 3, 1-4 (2010).

[26] M. Pecovska-Gjorgjevich, A. Andonovski, J. Velevska, Measuring frequency- and temperaturedependent permittivities of vegetable oils, Physica Macedonica, 59, 77-89 (2010).

[27] M. Pecovska-Gjorgjevich, J. Velevska, M. Najdovski, Dielectric analysis of sunflower and olive oil submitted to microwave radiation, Proceedings of First International Conference on Radiation and Dosimetry in Various Fields of Research, Niš, Serbia, 2 (2012). 